2003. - 273 с. 4. Закон України «Про інноваційну діяльність» // Відомості Верховної Ради України (ВВР). - 2002. - № 36. - Ст. 266 (зі змінами, внесеними згідно із законами від 2002-2005, 2010-2012). 5. Інтеграція : [словникова стаття] [Електронний pecypc]. - Режим доступу : http://uk.wikipedia.org/wiki/ Інтеграція. 6. Коменский Я. А. Избранные педагогические сочинения: [в 2-х т.] / Я. А. Коменский. - М., 1982. - 648 с. 7. Латинско-русский словарь: [ок. 50000 слов. - 3-е изд., испр.]. - М. : Рус. яз., 1986. 840 с. 8. Тенденции в глобальном высшем образовании: мониторинг академической революции [Електронний ресурс] / Доклад, подготовленный для Всемирной конференции ЮНЕСКО по высшему образованию 2009 года; перевод Е. Н. Карачаровой. - Режим доступу : http://unesdoc.unesco.org/images/0018/001831/ $183168 \mathrm{e} / \mathrm{pdf}$ 9. Шмир М. Ф. Міжпредметний підхід у формуванні діяльнісної компетенції студентів у вивченні німецької мови / М. Ф. Шмир // Педагогічний альманах ; зб. наук. пр. / редкол. В. В. Кузьменко (голова) та ін. - Херсон : РІПО, 2011. - Випуск 12. - Частина 2. - 293 с. - С. 221-224.

\title{
ФОРМУВАННЯ ПРОФЕСІЙНИХ ЦННОСТЕЙ КУРСАНТІВ МОРСЬКИХ НАВЧАЛЬНИХ ЗАКЛАДІВ ЗАСОБАМИ АНГЛІЙСЬКОЇ МОВИ (ЗА ПРОФЕСІЙНИМ СПРЯМУВАННЯМ)
}

Ляшенко У. І. Формування професійних цінностей курсантів морських навчальних закладів засобами англійської мови (за професійним спрямуванням).

У статті розглядається проблема формування професійних цінностей курсантів морських навчальних закладів засобами англійської мови (за професійним спрямуванням); акцентується увага на етапах формування професійних цінностей; визначено найбільш сприятливі умови для ефективного формування професійних цінностей курсантів морських навчальних закладів освіти; доведено, що найбільш ефективному формуванню професійних цінностей курсантів сприятиме впровадження етапів їх формування на заняттях з англійської мови (за професійним спрямуванням).

Ключові слова: професійні цінності, психолого-педагогічні умови, курсант, етапи формування, морські навчальні заклади, англійська мова (за професійним спрямуванням).

Ляшенко У. И. Формирование профессиональных ценностей курсантов морских учебных заведений средствами английского языка (профессиональной направленности).

В статье рассматривается проблема формирования профессиональных ценностей курсантов средствами английского языка (профессиональной направленности); акцентируется внимание на этапах формирования профессиональных ценностей; установлены наиболее подходящие условия для эффективного формирования профессиональных ценностей курсантов морских учебных заведений; доказано, что наиболее эффективному формированию профессиональных ценностей курсантов будет способствовать реализация этапов её формирования на занятиях по английскому языку (профессиональной направленности).

Ключевые слова: профессиональные ценности, психолого-педагогические условия, курсант, этапы формирования, морские учебные заведения, английский язык (профессиональной направленности). 
Lyashenko U. I. Formation of Cadets' professional values by means of Professional English.

The article is devoted to the problem of cadets' professional values formation by means of Professional English at maritime educational establishments; the stages of cadets' professional values formation are pointed out; the most suitable conditions for cadets' professional values formation are defined; it is proved that implementation of cadets' professional values at the Professional English lessons will be most effective.

Key words: professional values, psychological and pedagogical conditions; a cadet, formation of professional values stages, maritime educational establishments, Professional English.

Головною метою української системи освіти є створення умов для творчого розвитку та самореалізації особистості як професіонала і громадянина України, формування покоління, здатного навчатися впродовж життя, створення й розвиток цінностей громадянського суспільства (Освіта. Україна XXI століття). На сучасному етапі становлення суспільства перед системою освіти виникла потреба в розвитку професійних цінностей особистості- основне завдання яких: виховання в людині потреби в суспільно-корисній праці; правової та політичної культури, що виявляється в почутті власної гідності, внутрішній свободі особистості, дисциплінованості, у повазі та довірі до інших, здатності виконувати свої обов'язки, гармонійно поєднуючи патріотичні, національні та інтернаціональні почуття. Підготовка майбутніх морських професіоналів - це важливе i складне питання, що потребує комплексного i багаторівневого розв'язання, оскільки сучасне судно $\epsilon$ складним інженерним комплексом, що містить у собі різноманітне електричне та технічне обладнання, яке має обслуговуватись на належному рівні, і від того, наскільки майбутні спеціалісти оволодіють своїми майбутніми професійними цінностями та вміннями, залежатиме безпека судна та екіпажу загалом. У зв'язку з цим постає питання підготовки та формування професійних цінностей курсантів у морських вишах, що й зумовило тему нашого дослідження «Формування професійних цінностей курсантів морських навчальних закладів засобами англійської мови». Метою статті є вивчення особливостей формування професійних цінностей курсантів морських навчальних закладів засобами англійської мови (за професійним спрямуванням). Для реалізації поставленої мети нами визначено такі завдання: 1) розкрити етапи формування професійних цінностей курсантів на заняттях 3 англійської мови (за професійним спрямуванням); 2) виявити найбільш ефективні умови реалізації етапів формування професійних цінностей на заняттях 3 англійської мови (за професійним спрямуванням).

Аналіз психолого-педагогічної літератури свідчить, що питання професійного та морального розвитку особистості розглядалися такими науковцями, як І. Басецький, I. Бех, О. Буданов, М. Боришевський, Е. Голубєва, Г. Дубов, Г. Залеський, Л. Колодкін, О. Крупнов, О. Купленський, В. Лісовський, М. Савчин, В. Сухомлинський та ін.

Особливої актуальності проблема розвитку професійних цінностей набуває під час навчання курсантів морських коледжів, які у своїй професійній діяльності мають бути не лише кваліфікованими спеціалістами, а й носіями несуперечливої системи ціннісних орієнтацій, що в своїй основі спирається на загальнолюдські цінності та дозволяє гармонійно поєднувати патріотичні, національні й інтернаціональні почуття особистості. 
Серед засобів ефективного впливу на професійне становлення курсанта особливе місце посідає його діяльність, яка реалізується через наскрізну лінію цілеспрямованої роботи в умовах коледжу. Засвоєння професійних цінностей здійснюється через призму обраної професії, тих вимог, які висуваються до діяльності, поведінки, життєвої позиції ії носія і здійснюється як під час навчання, так і в позанавчальній діяльності [3, с. 267]. Однією 3 ефективних форм організації цілеспрямованого розвитку професійних цінностей курсантів морських коледжів $є$ заняття з англійської мови (за професійним спрямуванням). Вивчаючи іншу культуру та мову, спілкуючись англійською 3 носіями мови та викладачами, курсанти засвоюють систему професійних цінностей іншої нації, роблять порівняльний аналіз, знаходять подібне i відмінне та вибудовують свою власну систему цінностей, стаючи таким чином зрілою особистістю. Адже людина, яка досягла повноліття і поводиться в різних ситуаціях відповідно до загальнолюдських норм моралі, й основні цінності життя є ії власними цінностями, - зріла особистість [2].

Окрім цього, відтворюючи реальні життєві ситуації, курсанти здатні досягти необхідного рівня професійної компетентності, який допоможе їм реалізуватися як спеціалісту в майбутньому й убезпечити себе від можливих ризиків на морі: вчасне правильне розуміння отриманої інформації (яка надається англійською) зводить до мінімуму «людський чинник» створення небезпечної ситуації. Наведемо кілька прикладів із повідомлень, які ілюструють небезпечні ситуації на борту судна, причиною яких стало нерозуміння морської англійської мови та погана особистісна взаємодія [4, с. 25]:

1. Dear Sirs,

Please be informed that the damage to our vessel was not big. The reason of our going into the storm area was misunderstanding of a weather forecast by the Third Officer who was on watch at that time. His knowledge of English wasn't very good and he didn't understand the location of storm area.

Best Regards, John Wihlburn, Master.

2. Last Sunday container vessel «Agatha» collided with the dry cargo ship «Polar Star» in the Malacca Strait at 2.30 p.m. local time. One of the ships suffered damage on her hull portside. Another vessel's forepart was almost destroyed by the crash. The reason for this accident proved to be misunderstanding between to Watch Officers of the named ships during communication. Watch Officer of the container vessel didn't understand the message which was sent in English.

\section{Death at sea}

Mariner's News. - November 2, 2010

Yesterday the dead body of the engineering cadet was found in one of the holds of a chemical tanker. The doctor, who came aboard the vessel, told that the cadet died of intoxication as he came into the hold with dangerous toxic substances. The Master of the vessel considers himself responsible because he knew that the cadet didn't have a sufficient knowledge of English but he decided to give him a chance to improve his skills. All the information about the cargo is written in English and there was a warning sign on the door of the hold that it was dangerous to come inside without breathing apparatus. Probably, the cadet didn't understand this warning and came inside without proper equipment.

International Marine Time. - October 28, 2009

Аналіз причин цих небезпечних ситуацій на борту судна надає змогу зрозуміти, чому на ринку праці роботодавцями надається перевага морякам, які досконало володіють професійною англійською мовою, уміють правильно і вчасно оцінити 
ситуацію та здатні убезпечити себе та членів екіпажу від можливих небезпек, а то й просто виконувати свої обов'язки належним чином.

Міжнародна морська організація вивчила причини аварій на морі та зазначила, що у $80 \%$ випадків вони зумовлені людським чинником, а не технікою. Був проведений аналіз упливу комунікацій у морському середовищі на безпеку мореплавства та встановлений недостатній рівень основних мовних умінь, необхідних для спілкування та виконання професійних обов'язків. Відзначається низький рівень професійного мовного спілкування офіцерів суден 3 лоцманами, береговими службами. Ці проблеми призводять до непорозумінь, що особливо небезпечні в період аварійних ситуацій. Також виникають проблеми «внутрішнього спілкування» на суднах зі змішаним екіпажем: члени екіпажу не розуміють надписи, інструкції, настанови і тому не можуть ефективно діяти в екстремальних умовах [5]. Міжнародна організація (IMO) зазначає, що за рік трапляється більше 100 фатальних інцидентів через проблеми із знанням англійської мови, тому (IMO) визначила перелік обов'язкових стандартних морських фраз для спілкування, якими повинен оволодіти кожен майбутній професіонал для запоруки безпеки на борту судна.

Розглядаючи етапи розвитку професійних цінностей курсантів морських коледжів на заняттях 3 англійської мови, ми будемо спиратись на наукову розробку I. Беха, за якою розвиток будь-якої особистісної цінності передбачає створення адекватної її сутності перспективи спільної діяльності педагога й учня [1, с. 115]. Так, ми виокремили такі етапи розвитку професійних цінностей курсантів морських коледжів:

- на першому етапі змістовою основою реалізації розвитку професійних цінностей курсантів морських коледжів має бути виокремлення сфери дії професійних цінностей у судноплавстві як особистісних цінностей майбутніх професіоналів;

- на другому етапі діяльність з розвитку професійних цінностей на заняттях 3 англійської мови зосереджується на формуванні впевненості курсантів морських коледжів у доцільності набуття цих особистісних цінностей;

- на третьому етапі, після глибокого усвідомлення курсантами сфери діяльності, їхню увагу необхідно звернути на те, що саме професійні цінності в особистіснопрофесійному становленні необхідні їм для майбутньої професійної діяльності, тобто сформувати емоційно-смислове ставлення до професійних цінностей як цінностей особистості.

Для ефективного впровадження цих етапів розвитку професійних цінностей необхідно створити відповідні психолого-педагогічні умови для їх формування в курсантів морських навчальних закладів. На наш погляд, такими умовами є:

- організація та стимулювання рефлексивної діяльності курсантів на заняттях 3 англійської мови (за професійним спрямуванням) для орієнтації на професійні цінності;

- формування творчої особистості як могутнього стимулу духовного життя громадянина незалежної держави під час рольових ігор;

- урахування основних засад становлення та розвитку курсантів, їх світогляду, переконань, професійної діяльності;

- професійна орієнтація курсантів на ідеал сучасного фахівця як носія фахових знань, умінь і навичок;

- реалізація відкритої системи зв'язків із суспільством, запровадження методів та форм активної професійно-творчої діяльності;

- адаптація і готовність викладачів дисципліни «Англійська мова (за 
професійним спрямуванням)» реалізовувати потенціал своєї дисципліни щодо формування професійних цінностей курсантів;

- цілеспрямоване засвоєння значущих для професійної діяльності умінь і навичок: постійне збагачення пам'яті, громадянського мислення, вироблення свідомого ставлення до навчання, самоосвіти;

- удосконалення управління процесом формування професійних цінностей на заняттях з англійської мови (за професійним спрямуванням).

Ураховуючи те, що розвиток професійних цінностей курсантів морських навчальних закладів повинен відбуватись у три етапи і сприяти формуванню в них несуперечливої системи ціннісних орієнтацій, можна зробити висновок, що впровадження цих етапів на заняттях 3 англійської мови (за професійним спрямуванням) 3 урахуванням визначених психолого-педагогічних умов, дозволить курсантам гармонійно поєднувати патріотичні, національні та інтернаціональні почуття, ставитись 3 повагою до цінностей інших народів у своїй професійній діяльності, а отже, сприятиме найбільш ефективному формуванню професійних цінностей майбутніх морських фахівців.

Перспективу подальших досліджень убачаємо у виявленні необхідних методів і форм формування професійних цінностей курсантів у процесі вивчення англійської мови (за професійним спрямуванням).

\section{Література}

1. Бех І. Д.Виховання особистості. К. 2. «Особистісно орієнтований підхід: науково-практичні засади / І. Д. Бех. - К. : Либідь, 2003. - 320 с. 2. Бодалев А. А. Вершина в развитии взрослого человека. Быть профессионалом в психологии - это обязательно [Электронный ресурс]/ А. А. Бодалев. - Режим доступа: http: //hpsy.ru/public/x797.htm 3. Кудрявцева В. Ф. «Welcome Aboard». Student's Book. - Херсон: Грінь Д. С. - 2013. - 220 с. 4. Пимошенко А. «Безопасность мореплавания. Понять - значит спастись» / А. Пимошенко. - Калининград, 2003. $320 \mathrm{c}$.

УДК 004.912

Павло Мерзликін, Наталя Хараджсян

\section{РОЗРОБЛЕННЯ ШАБЛОНУ ОФОРМЛЕННЯ ПОЯСНЮВАЛЬНОЇ ЗАПИСКИ КУРСОВОЇ РОБОТИ ЗАСОБАМИ ХМАРНИХ ТЕХНОЛОГІЙ}

Мерзликін П. В., Хараджян Н. А. Розроблення шаблону оформлення пояснювальної записки курсової роботи засобами хмарних технологій.

У статті розглянуто можливість створення шаблону оформлення курсової роботи засобами хмарних технологій, що полегшить роботу над оформленням тексту згідно 3 висунутими до нього вимогами. Шаблон також може бути адаптований для використання в інших вищих навчальних закладах та для оформлення тексту кваліфікаційної роботи.

Ключові слова: шаблон, пояснювальна записка, хмарні технології, системи комп'ютерної верстки, LaTeX.

Мерзликин П. В., Хараджян Н. А. Разработка шаблона оформления пояснительной записки курсовой работы средствами облачных технологий.

В статье рассматривается возможность создания шаблона оформления курсовой 